\title{
PAPER SCHOOL OR FLESH AND BLOOD SCHOOL? PEDAGOGIC ANALYSIS OF SOME SYMPTOMS OF SUFFERING IN CONTEMPORARY SCHOOLS
}

\author{
Stefania Ulivieri Stiozzi \\ University of Milan-Bicocca
}

\begin{abstract}
This article reflects upon some paradoxes concerning the reality of Italian contemporary school, after more than ten years from the decree enforcing the scholastic autonomy. Starting from the contribution by a teacher selected for his ability to give evidence of the sense of deep unease experienced by the teachers working in the school system, my text highlights the gaps emerging from the law regulations directed to the emphasis of the organizational transformation of the school and the real school, which is asking to review its global educational mandate and revamp the symbolic value of its local culture.
\end{abstract}

Key words: local culture, education, group, school, institution, organization,

\section{Deserting school}

Many attempts have already been made to weigh the impact of the effects produced by the Program of Scholastic Autonomy after more than ten years from its implementation, in terms of changes and changes of the overall quality of the formation offered by the school. As Puttilli stated: «After over a decade from its implementation, also the scholastic autonomy, like many other "strategic" reforms adopted in our Country, appears to be only half a reform"»" (Putilli, 2011).

Aim of such a reform was mainly to transform the centralized school system and even up the management of the resources, by turning the school, or better, the network of schools on the territory, into a system capable to perform an analysis of the formative needs, of the resources and ties of the context to structure a formation plan offered that could meet the requirements of every single local reality.

The stated intent was to go from the assumption of a universal school, heritage of the Gentile's model, to a more capable school, thanks also to a direct management of the funds, to express its own local educational identity, by mean of a planning able to respond to families', students' and, in general, territory's demands, to elaborate them and therefore to produce formative and educational targeted projects.

In the state of turmoil that characterized the first reactions following the autonomy, if on the one hand the most diffused concerns as regards to the decentralization were related to the drift of a school-firm, excessively competitive and centered on a model of effectiveness not appropriate to its specific educational mandate, on the other hand the hopes of those working within the school system (teachers, executives, pedagogists, parents, etc.), were 
that the school could strengthen its matrix of pedagogic and cultural filter of the distinctive contradictions of its local reality.

The general wish was that schools could become more permeable to the sense of unease brought in by the students and, thanks to this grassroots approach, could build an autonomy not so much and not only managerial, but above all pedagogic, by developing greater sensibility and awareness of their internal issues and greater responsibility and courage to solve them out.

Many have seen in this reform a challenge for schools to emerge from the structural immobilism and develop new forms of creativity and pedagogic experimentation that could strengthen its profile and full commitment as formative and educational agency.

Thirteen years have passed since that new founding phase, as with this brief contribution I would like to analyze some unsolved core topics that keep questioning my work as educator, pedagogical consultant and researcher working side by side with school and university teachers. Today, resistances are the main place to question in order to understand what has not been thought over yet and what is hampering that shift toward a new form-school we all wish to witness.

Recently, as I was surfing the web, i came across a sorrowful comment by a teacher, that is the most extreme implication of the diffused sense of unease I have personally heard many times, directly from the teachers' words:

I can write about everything and $i$ have been teaching for almost thirty years now. Still, schools live in such a state of abandonment, even i struggle to write about it. With all the due exceptions, schools are the place for deserters. Teachers pretend to teach. Pupils pretend to learn. Executives pretend to execute. And then there is another problem. When talking about school, nobody ever talks about real school, that is all these classrooms hosting millions of people every morning. Instead, people talk about paper school: programs, reforms and counter-reforms, updatings, scheduling. It's the school written in circulars, the school of registers, a true hallucination compared to real life, made of chairs and desks and exhausted or bored bodies. ${ }^{1}$

I would like to question this short article of mine to start reflecting upon some symptoms of suffering currently affecting the school system and some of unsolved core topics of its functioning. It is interesting to question my article from a clinical perspective (Massa, 1992; Riva, 2000; Rezzara, 2005) and read it as a synthesis of the critical issues and as a symptom of the hard work those personally and daily involved with school have to face.

Writing, says this teacher, would report his inadequacy since the duty of those who write is to highlight the importance of a real problem, but if the school is a

\footnotetext{
${ }^{1}$ Reference from website:.http://comunita provvisoria.wordpress.com/2008/09/14/la-scuola-dei-disertori. I went through different aspects drawn by an analysis of the latencies in this text, I reported in a recently published essay. See: Ulivieri Stiozzi, S. La parola è l'evento. La scuola come scena educativa in Marone, F, Striano, M. (2012), Cultura postmoderna e linguaggi divergenti, Milano: FrancoAngeli.
} 
territory emptied of meanings, what could be possibly written and above all, by whom? Where a voice could possibly position itself, if it is not rooted in an alive place? Where can the voice start speaking from? Schools, absent with those who inhabit them, don't ask for words but for quality experiences different from these in use, above all experiences connecting people, space, practices and reflections within a discussion different from the one brought up by regulation programs, circulars and from the continuous legislative changes that affected school in recent years.

The issue arising from the teacher's words is whether discussing the changes in the organization structure could be enough to create a truly practicable horizon of transformability, or whether the unbalancing itself on this side of the discussion could be the symptom of a highly expensive desertification of the cultural project of schools.

The school system meant as an effective organizational apparatus, comes from a rationalistic-illuministic mentality where the law regulations on the school system coincide with its real institutional functioning and its best practice is connected to a clear and transparent legislative apparatus. The teacher reports a break between discussions and practices, a gap that has not been thought between idea and reality: the materiality of school is unrelated to this project of change and so is the substance of education itself: the unthought matter of education is not just made of those who take part to the life of schools, but the matter of education itself has become thinner and thinner, it almost vanished.

I was impressed by the lack of an integrating background recalled in the teacher's words in the attempt to identify the pedagogic roots of School; it appears clear that the form is missing, the frame capable of including the overall project and providing for its profoundness is missing too.

Using an aesthetical reference, I would like to analyze the use of the verb pretend, as reported by the teacher, starting from the metaphor of the «school like a theater» (Massa, 2001). Massa deeply analyzed the authenticating function of education comparing it to the theater; two tools that, through their fictionality enable an intense relationship with the vital experience, making it more authentic.

If the theater fictional dimension reminds of the ability of actors to create a three-dimensional world, a duplicate of life going on stage, more real than reality for its ability to express in distilled form the relationship with the inspiration coming from the place, so schools where people pretend to teach and educate express the betrayal of the creative paradox from which the sole educational experience can be created. From my experience, the act of pretending reminds to a relationship with the place and the mission that is not physical, to the emulation of a teaching style without profoundness, without roots in the here and now experience by the class and its time/space dimension 
of learning. A limelight dimension of the School instead of a stage dimension ${ }^{2}$ : this is what appears from the teacher's words, a comedy of roles unable to give profoundness to the overall formative project, made of pedagogic actions upon which reflecting, made of educational gestures to be translated in thoughts and turned into new and more refined and aware actions.

Schools seem to have given up on their educational commitment expressed by a virtuous circularity going from doing to feeling to thinking, which would allow the class to go back on stage supported by a thought more articulated, more critical and opened to new hypotheses of intervention.

Working as an educator of teachers makes me personally witness this diffused sense of unease felt by the whole category, unable to connect their own actions and create a sensible frame shared by the teaching staff that could build, in time, a common thought to be turned into local culture, starting from the daily experience lived in the classroom. The demand for new ways to interpret the teaching role, more opened not only to the didactic management but also to reciprocity and cooperation within the staff in the phases of planning and evaluation has been jeopardizing in recent years the model of «prescription of the professional role» (Benadusi, 2002) centered on the disciplinary knowledge achieved and its implicit evaluative apparatus.

This crisis has not been opposed by any initiative promoting appropriate formation programs, so today teachers find themselves in a transitional condition: what is considered old seems obsolete, at the same time they don't feel supported in their migration into a new role, of which limits, competences and new goals can hardly be identified. Teachers I meet daily feel the new responsibilities and new challenges toward a more complex, faceted and critical professionalism, able to take advantage of the opportunities offered by the local realities, but they also fear the risks of what they do, they feel their job is almost impossible to be done - like building a cathedral in the desert - unless a new culture, a new way to intend school make its way on different levels, going through the mandate of the school management and the welfare recovery that could support it in this difficult transition.

How is it possible to transform the educational practice lived in classes into an aware educational thought and into a culture at the base that comes from the elaboration of the cognitive and emotional work done by teachers while exposed to the glance of their classes? (Schon, 1983). Who is protecting this activity of containment, of struggling thought generated when giving shape to experiences that are certainly painful, but rich in their subtext, and instead go usually missing, wasted, leaving the place deprived of such an abundant material that has not been elaborated? (Bion, 1962)

\footnotetext{
${ }^{2}$ Analysis of the difference between stage and limelight in theater, see: Goffmann, E. (1959), The Presentation of Self in Everiday Life, , New York:Doubleday Anchor Books.
} 
The professional suffering that teachers experience in schools is neither linked to the relationship with the students, ever more disorientated and reluctant to get emotionally involved in the class activity, nor to the communication with families with which communication has become ever more difficult to establish, a kind of communication centered on the awareness of the educational duty and mutual positioning. Instead, it is linked to the absence of the management, which creates a great sense of emptiness as regards to ideation and pedagogic planning. Teachers experience this absence as a lack of institutional boundaries that generates strong anxiety from stress and a diffused sense of instability and frustration on the long term.

As the Autonomy regulation became effective, we thought that schools could have been able, with the recognition of the scholastic leadership, to plan more farsighted projects, supported and directed by a solid organization. The boosts to engage a managerial role, related to an attitude business oriented, based on local initiatives and decisional autonomy, have been turned into an emphasis of the evaluation of quality, seen mainly from a business perspective. The school system was unprepared to receive a culture of leadership as it was, without proper translations from the business world, as the management ended up covering the role of accounting administrators rather than the more appropriate role of promoters of new visions in the organization and formative planning. The scarce investment in new formation programs of new scholastic management for the exploitation of human and professional resources within a systemic vision open to new forms of followership incentive, has weakened the role of managers, by flattening it to a bureaucratic level of executives in charge of the carrying out of ministerial directives and accounting inspectors, closed within the logic of exasperate costs contraction, that it's got nothing to do with cost saving policies.

Nowadays, what schools are missing is a role capable to embody a pedagogic project, to build a culture based on trust and delegation, and to give roots to sensible coordinates that can be identifying, supporting elements for teachers committed to elaborate and creatively transform the suffering that schools inevitably produce.

It's also missing the role of someone able to lever up the desire of those who still invest much in teaching as a vocational job, those who, through more explicit and known forms of delegation, could become a point of reference of the school pedagogic project, by driving the work groups toward the achievement of objectives requiring in-depth reflexive analysis.

Teachers often refer to school boards as self-referring places, where the relation with the substantial core of the teaching experience is missing, where rigid interpersonal models and pathological forms of communication rule.

The prevailing individualism culture, in absence of symbolic limits that can direct it toward a common good-based culture, turns the groups into pure aggregates that must accomplish to the organizational duty, and misses the 
opportunity to run towards a collective growth, that could be possible thanks to the integration with the differences within the group and the exercises of conflict.

Recently, some teachers I met during the formation paths reported scenes of verbal and physical abuse during board meetings, attesting these groups' functioning to the level of «basic assumption group» ${ }^{3}$ (Bion,1962). The lack of an integrating symbolic background, the lack of a patrimony of shared and shaped sense, produce in teachers motivated a personal overexposure too onerous, and force the less motivated into an obsolete, anachronistic teaching practice, into a role impermeable to the stimuli offered by the colleagues and the context.

Education for citizenship, promoted by the current European policies, it's a complex process that integrates the civil and political socialization of the citizens' future and its ability to make sense to human values in a democratic society.

This process of change cannot be completed without dramatically reviewing the system School. How can we have a culture based on solidarity and civil education without the school taking active part to this process? Students in schools don't learn just contents, they breathe a modus vivendi, they experience an environment made of actions and meaningful gestures, as well as omissions and lacks that mark their identities. At school, they breathe the institutional anxiety as well as they absorb the family atmospheres at home and on this background not explicit they build up the sense of values, the relationship with the dimensions of respect, of identity value and solidarity.

When questioning the revision plans of the primary school system introduced by the Gelmini (Italy's Minister for Education) decree, further elements emerge in favor of this project of deflagration of education and emphasis on the organizational container, seen as a guide for future school. As reported in the scheme of program issued by the Ministry for Education: «In primary school, the obligatory time schedule of educational activities, in the pursuit of a progressive generalization and considering the families' different demands, is carried out also in the sole forenoon, with only one teacher per section and reorganizing as much as possible the operation activities within the school

\footnotetext{
${ }^{3} \mathrm{~W}$. Bion refers to basic assumption as the group specific mechanism of defense; that is unconscious fantasies leading to a self-referential behavior that guarantees the group survival. In other words, when a group adopts the basic assumption it interferes with the task the group is attempting to accomplish. Bion identified three basic assumptions: dependency, fight-flight and pairing. They activate in institutional groups when a sense of emptiness is felt within this institution mental container (changes within the management or lack of a powerful guide within the institution, etc.). These are unconscious mental states, but they can be easily referred to the "pathological" behavior of the group. When a group adopts any one of the basic assumptions, it interferes with the task the group is attempting to accomplish unless, by working on the members' experiences, the group crosses this level and concentrates on the achievement of the shared goal. For a closer look of these group dynamics, see: Corrao, F. (1981), "Bion: il modello trasformazionale del pensiero", in Rivista di Psicoanalisi, XXVII, 3-4.
} 
sections on the base of such options. Consequent spare hours and places might enable new activations and consequently the extension of the service» ${ }^{4}$.

By highlighting the matter of time, translated as amount of hours spent for educational activities, we are brought back to the topic of School as organizational container. Performing scholastic activities in a shorter time leads to time saving and, obviously, cost saving. But the full-time system upon which the pedagogic experience of Italian primary school was based for years is not just a mere alternative organizational container, but instead a form-school with its specific internal quality. It was the background for shared planning among teachers, thought within to a community system, the form inside which the pedagogic value was translated in reported life experiences, which were strengthening the cultural identity of that single school before its territory.

If this process produced different results in terms of quality, in reason of the complex mechanism of geographic, social and economic variables within the school population, it certainly represents an important reference to understand how creative the process of being part of the school can be, a process intrinsically compared to the ties and resources represented by the community operating inside the school.

The single teacher suggested by the reform is instead a teacher on his own, working in a place deprived of resources, of human energy, in a place that is not providing for that symbolism that could be used to develop a pedagogic creativity, but translates into an organizational container for duties quantified in amount of hours.

In a place that loses its symbolic matrix that produces actions and thoughts, the relationship between teacher and students is likely to be emphasized, to become container of expectations concerning an ideal relationship, characterized by deceptive fantasies and inevitably exposed to significant risks. The Program indeed refers to this ideal role of the teacher who, thanks to a strong vocation and talented personality, should be able to conquer the soul of entire generations of students, fascinated by the teacher's maieutic personality.

But how can this nineteenth-century idea of the teacher, heritage of the more conservative collective fantasies, grow within schools that no longer wish to express an authentic pedagogic function, promoting and taking care of the place? How can teachers, on their own, fill the structural gaps, if this emptiness stays out of a thought that is institutionally shared? How can formation fill this gap?

\footnotetext{
${ }^{4}$ Reference from Education Plan by the Ministry of Education, University and Research, together with the Ministry of Economy and Finance, under art.64 of law-decree June 25ft 2008, n.112.
} 


\section{Conclusions}

As reported on / edited by the association Treelle« twenty years of research, above all in English-speaking countries, indicate two main factors at the base of best performing schools: a) teachers' quality, b) management's quality. Indeed, international studies highlight that the professional quality of the principal and his/her team can have a crucial influence on the school qualitative standards.» ${ }^{5}$ In our country instead, research on the relationship between the professional quality of the executive, the teachers' team work and the quality of the overall scholastic experience is extremely poor. This is due to a diffused assumption that sees the School as a professional community that could work without a leadership.

But teachers become a community only when the management is able to build a culture of leadership, where the team of teachers is responsible for the research and formation assignment and only if the scholastic context can become a place where new competences of observation, shared exchange, reflexive action and planning of best practice monitored and evaluated can be activated.

Today, teachers are the spokespersons of a defined institutional discomfort, that indeed reveals itself mainly in the shape of psychiatric and psychosomatic disorders, which is becoming a social threat, as proved by the ever growing interest shown by the media. Such discomfort can be related to the lack of a symbolic garrison within the School. Teachers' and students' suffering indicates that something in this project of half a change is not working.

The exhausted, bored bodies to which the teacher's comment refers certainly aren't just a metaphor, but rather the waste in flesh and blood of an ideology that pushes to have a school system like a social duplicate; a school where pedagogy is identified with the current ethics, not with a process of creative mimesis, an artificial tool showing a socially legitimated scene, instead of a theatrical game where the roles can be rearranged and transformed.

In order to change, the school system should do some research on the organization as a form within which its pedagogic mandate can be declined. Only by thinking of the organization as a productive articulation of the school educational project, the division can be reset and the discomfort can be understood and overcome. To monitor this change, we need formation resources and a refined pedagogic thought reassessing the value of School as a privileged place of real experience and cultural reprocessing.

\footnotetext{
${ }^{5}$ Treelle Association, "Quale dirigenza per la scuola dell'autonomia? Proposte per una professione nuova", n.7, December, 2007.
} 


\section{Summary}

This article reflects upon some paradoxes concerning the reality of Italian contemporary school, after more than ten years from the decree enforcing the scholastic autonomy. Starting from the contribution by a teacher, a perfect example to give evidence of the diffused discomfort within the teachers' category, the article focuses on how the Reform failed its goal to achieve a scholastic effective performance, in reason of a cultural short sighted vision that led the institutions to think of the changes within the school system related to its organizational frame, instead of framing it within a radically new vision of its pedagogic nature.

A school made of decrees and laws doesn't reflect the heterogeneity of the local scholastic experiences, that struggle to build a pedagogic project strictly related to the needs of teachers, students and families, in territories diversified of which the formative and educational demands need to be processed.

The lack of a cohesive team of pedagogic planning and executives able to reflect upon the specificity of each scholastic experience, lead to irregular models and educational methods that cannot be integrated with an institutional culture impoverished of real experiences.

My text highlights the gaps emerging from the law regulations directed to the emphasis of the organizational transformation of the school and the real school, which is asking to review its global educational mandate and revamp the symbolic value of its local culture.

\section{Bibliography}

1. A.A.V.V, (2005), The essentials of School Leadership, London: Paul Chapman Publishing and Corwin Press.

2. Antonacci F., Cappa,F., (2001), Riccardo Massa. Lezioni su la peste, il teatro, l'educazione, Milano: FrancoAngeli.

3. Armone, A., Di Mauro, M. (2006), Progettare a scuola. Strumenti di programmazione delle attività educative, Roma: Carocci.

4. Bainbridge, A., West, L. (2012), Minding a gap. Psychoanalysis and Education. London: Karnac.

5. Ball,S. (2003), Class strategies and the Education Market: The Middle Class and Social Advantage, London-NewYork: Routledge.

6. Ballarino G., Checchi, D. (2006) (a cura di), Sistema scolastico e disuguaglianza sociale, Bologna: Il Mulino.

7. Benadusi, L. (2002), La "logica competenza" nella scuola in Benadusi, L.-Di Francesco, G. (a cura di), Formare per competenze. Un percorso innovativo tra istruzione e formazione, Napoli: Tecnodid, pp 7-72.

8. Benadusi, L., Consoli, F. (2004) ( a cura di), La governance della scuola, Bologna: Il Mulino.

9. Bion W.R. (1962), Learning from Experience, London: William Heinemann.

10. Bottani, N., Benadusi,L. (2006) ( a cura di),Uguaglianza e equità nella scuola,Trento: Erickson.

11. Cifali M. (1994), Le lien éducatif: contre-jour psychanalytique, Paris: PUF.

12. Contini, M.G., Fabbri, Manuzzi, P. (2006), Non di solo cervello. Educare alle connessioni mente-corpo-significati-contesti, Milano: Cortina. 
13. Corrao, F. (1981), Bion: il modello trasformazionale del pensiero. In Rivista di Psicoanalisi, XXVII, 3-4.

14. Goffmann, E. (1959), The Presentation of Self in Everiday Life, New York: Doubleday Anchor Books.

15. Gordon, T. (1974), T.E.T.: Teacher Effectiveness Training, New York: Crown Publishing.

16. Lagrasta,G. (2004), Managment scolastico integrato. Network organizzativi e reti sociali, Roma: Anicia.

17. Mantegazza R. (2003), Pedagogia della resistenza, Enna: Città Aperta.

18. Massa R. (1987), Educare o istruire? La fine della pedagogia nella cultura contemporanea, Milano: Unicopli.

19. Massa R. (1993), La clinica della formazione, Un'esperienza di ricerca, Milano: FrancoAngeli.

20. Massa R. (1999), Cambiare la scuola, Bari-Roma: Laterza.

21. Mottana P. (1993), Formazione e affetti. Il contributo della psicoanalisi allo studio e all'elaborazione dei processi di apprendimento, Roma: Armando.

22. Neri C. (2004), Gruppo, Roma: Borla.

23. Parmigiani,D. (2010), Tra il dire e il fare. Come si decide a scuola: dalla riunione alla classe, Milano: Angeli.

24. Puttilli, N. (2011), La scuola dell'autonomia come bene collettivo in Scuola Oggi. org www.flcgil.it.

25. Quero,C. et al. (2005), Organizzare la scuola della riforma. I processi di attuazione come la personalizzazione, la flessibilità, l'ologramma, Bari: Milella.

26. Recalcati M. (2011), Cosa resta del padre, Milano: Cortina.

27. Rezzara A., Cerioli, L. (2005), La consulenza clinica a scuola, Milano: FrancoAngeli.

28. Riva M.G. (2000), Studio “clinico” sulla formazione, Milano: FrancoAngeli.

29. Riva, M.G. (2005), Formazione clinica e pratiche di autoriflessione per dirigenti scolastici, Pisa:ETS,.

30. Rogers C. (1969), Freedom to learn, Ohio: Columbus.

31. Schon, D.A. (1983), The Reflexive Practioner, New York: Basic Books Inc.

32. Ulivieri Stiozzi, S. et al. (2004), Formazione clinica e sviluppo delle risorse umane, Milano: Angeli.

33. Ulivieri Stiozzi, S. (2012) La parola è l'evento. La scuola come scena educativa in Marone, F, Striano, M. (a cura di), Cultura postmoderna e linguaggi divergenti, Milano: FrancoAngeli, pp.119-138.

\begin{tabular}{|c|l|}
\hline Confirmed researcher & Department of Educational Human \\
Stefania Ulivieri Stiozzi & Sciences \\
& University of Milan-Bicocca \\
& Piazza dell'Ateneo Nuovo 1 \\
& E- mail:stefania.ulivieri@unimib.it \\
& Tel:0264484833 \\
\hline
\end{tabular}

